\title{
KONSEP ASNAF PENERIMA ZAKAT MENURUT PEMIKIRAN YUSUF AL-QARDAWI DAN WAHBAH AL-ZUHAYLI
}

(Sebuah Analisis Komparasi)

\author{
Intan Sherly Monica ${ }^{{ }^{*}}$ Atik Abidah ${ }^{2 *}$ \\ 1,2 Fakultas Syariah, IAIN Ponorogo \\ 1Email: intangandhini411@gmail.com \\ 2Email: atikabidah050876@gmail.com
}

\begin{tabular}{l|l|l}
\hline \multicolumn{3}{l}{ DOI: } \\
\hline Received: $30-7-2021$ & Revised: $17-8-2021$ & Approved: $29-8-2021$ \\
\hline
\end{tabular}

Abstract: This article discusses the Asnaf zakat according to contemporary scholars, namely Yüsuf Al-Qardawī and Wahbah Al-Zuhaylï. This work aims to explain the similarities and differences in the thoughts of the two figures regarding asnaf zakat. The method used is library research by examining the books of the two figures, namely Fiqhuz Zakat and Islamic Fiqh wa Adilatuhu. It can be concluded that the thoughts of Yüsuf Al-Qardawi $\bar{i}$ and Wahbah Al Zuhayli on the eight groups of zakat recipients are not much different. It's just that there is a slight difference that is most significant in the fí sabilillah group where Yüsuf Al Qardawī argues that this group is extended to the meaning of fighting in the way of Allah such as charity for the public interest, this is in accordance with the opinion of some scholars who expand the meaning of fi sabilillah. Meanwhile, according to Wahbah Al-Zuhayli the meaning of fi sabilillah is soldiers who fight but are not paid by the state, this is in accordance with Q.S ash-Shaff: 4. And from their opinion, Yüsuf Al Qardawi's thoughts are the most relevant to the condition of the Indonesian state. The istinbāth method used by the two figures is dominant in ijma'. And what influenced his thinking the most was the role of the teacher and the social conditions of the two figures.

Keyword: Asnaf Zakat, Wahbah Al Zuhaili, Yüsuf Al Qardawī.

\begin{abstract}
Abstrak: Artikel ini membahas tentang Asnaf zakat menurut ulama kontemporer yaitu Yüsuf Al-Qardawì dan Wahbah Al-Zuhayli. Karya ini bertujuan untuk menjelaskan persamaan dan perbedaan pemikiran kedua tokoh tentang asnaf zakat. Metode yang digunakan adalah penelitian pustaka dengan mengkaji kitab kedua tokoh yakni Fiqhuz Zakat dan Fiqh Islam wa Adillatuhu. Dapat disimpulkan bahwa pemikiran Yüsuf Al-Qardawi dan Wahbah Al Zuhayli terhadap delapan golongan penerima zakat tidak jauh berbeda. Hanya saja terdapat sedikit perbedaan yang paling signifikan pada golongan fí sabilillah dimana Yüsuf Al Qardawi berpendapat bahwa golongan ini diluaskan pada makna berjuang di jalan Allah seperti amal untuk kepentingan umum, hal itu sesuai dengan pendapat beberapa ulama yang meluaskan arti fi sabilillah. Sedangkan menurut Wahbah Al-Zuhayli pemaknaan fi sabilillah ialah para tentara yang berperang namun tidak digaji oleh
\end{abstract}


negara, hal tersebut sesuai dengan Q.S ash-Shaff:4. Dan dari pendapat keduanya, pemikiran Yüsuf Al Qardawi lah yang paling relevan dengan kondisi negara Indonesia. Metode istinbäth yang digunakan oleh kedua tokoh adalah dominan pada ijma'. Dan yang paling mempengaruhi pemikirannya adalah peran guru serta kondisi sosial kedua tokoh.

Kata Kunci: Asnaf Zakat, Wahbah Al Zuhaili, Yüsuf Al Qardawì.

\section{PENDAHULUAN}

Zakat merupakan ibadah yang diatur dalam rukun Islam ke-empat dan merupakan pilar tegaknya agama Islam. Dalam istilah ulama fikih, zakat berarti penyerahan wajib sebagian harta kekayaan kepada golongan orang yang berhak menerimanya melalui amil, penyerahan harta untuk mencari keridhaan Allah SWT sesuai dengan ketentuan syari'at. ${ }^{1}$ Zakat termasuk ibadah mâliyah ijtima"iyyah yang memiliki posisi sangat penting, strategis dan menentukan, baik dilihat dari sisi ajaran Islam maupun dari sisi pembangunan kesejahteraan umat. ${ }^{2}$ Zakat diyakini mampu mengatasi masalah sosial, diantaranya mengentaskan kemiskinan dan mengurangi kesenjangan pendapatan masyarakat. ${ }^{3}$ Esensi dari hikmah ibadah zakat adalah menolong, membantu, menyantuni orang-orang yang tidak mampu dan orangorang yang sangat membutuhkan pertolongan, serta penyeimbangan pemanfaatan harta, agar harta itu tidak hanya berada di tangan orang-orang kaya saja (aghniya'). ${ }^{4}$

Perintah untuk menunaikan zakat tersebut termaktub dalam surat AtTaubah ayat 60, berikut "Sesungguhnya sedekah-sedekah (zakat) itu hanyalah untuk orang-orang fakir, dan orang-orang miskin dan amil-amil yang mengurusnya dan orang-orang mualaf yang dijinakkan hatinya dan untuk hamba-hamba yang hendak memerdekakan dirinya, dan orang-orang yang berhutang dan untuk (dibelanjakan pada) jalan Allah, dan orang-orang musafir (yang keputusan) dalam perjalanan. (Ketetapan hukum yang demikian itu ialah) sebagai satu ketetapan

1 Mohd Abd Wahab Fatoni Mohd Balwi, "Mobilisasi Zakat Dalam Pewujudan Usahawan Asnaf: Satu Tinjauan," Jurnal Syariah 16, no. 3 (1 September 2008): 567-84.

2 "Pandangan Ulama Tentang Zakat Perusahaan | Syakhsia : Jurnal Hukum Perdata Islam," 11-24, diakses 12 Agustus 2021, http://103.20.188.221/index.php/syakhsia/article/view/4879.

3 Ubabuddin dan Umi Nasikhah, "Peran Zakat, Infaq Dan Shadaqah Dalam Kehidupan," AlMuttaqin : Jurnal Dakwah Dan Sosial Keagamaan 6, no. 1 (24 Februari 2021): 60-76.

${ }^{4}$ Ahmad Imam Jazuli, "Makna Fisabilillah Sebagai Mustahiq Zakat (Studi Komparasi Antara Ahlus Sunnah Wal Jama'ah Dan Wahabi)," Journal of Islamic Business Law 5, no. 1 (31 Maret 2021): 37-47, http://urj.uin-malang.ac.id/index.php/jibl/article/view/624. 
(yang datangnya) dari Allah. Dan (ingatlah) Allah Maha Mengetahui, lagi Maha Bijaksana."5

Salah satu tujuan zakat yaitu untuk mendekatkan diri kepada Allah dan menyejahterakan umat manusia, maka zakat harus benar-benar diberikan kepada orang yang berhak menerima. Sesuai dengan yang terdapat dalam QS. At-Taubah ayat $60^{6}$ yang secara eksplisit menentukan bahwa pemanfaatan zakat bersifat khusus dan terbatas untuk delapan golongan. ${ }^{7}$ Pendistribusian zakat merupakan perintah zakat yang dilakukan dan diberikan kepada golongan sesuai dengan hukum syara', maka hal tersebut akan mendatangkan kemaslahatan. ${ }^{8}$ Siapa saja sebenarnya sasaran zakat itu? Beberapa ulama berbeda pendapat dalam mendefinisikan makna dari masing-masing golongan yang telah disebutkan dalam al-Qur'an. Perbedaan pendapat ini tentu bermula dari perbedaan dalam memahami teks al-Qur'an yang diturunkan untuk memberikan keterangan kepada siapa saja harta zakat didistribusikan. Tidak terkecuali pendapat ulama kontemporer Yūsuf Al Qarḍwī dan Wahbah Al Zuhayli tentang konsep mustahiq zakat. Keduanya merupakan ulama yang pemikirannya telah banyak dipengaruhi oleh beberapa hal.

Terkait dengan topik ini, terdapat beberapa kajian terdahulu yang relevan. Diantaranya pertama, penelitian Nova Sandy Prastyo, ${ }^{9}$ tentang "Perbandingan Antara Yūsuf Al-Qardawī dan Wahbah Al-Zuhayli Tentang Zakat Perusahaan". Penelitian tersebut menjelaskan hukum mengeluarkan zakat perusahaan menurut Yūsuf Al Qardawi adalah wajib. Sementara menurut Wahbah Al Zuhayli juga wajib dengan lebih melihat karena adanya illat yang membuat hukum itu berubah.

${ }^{5} \mathrm{Al}$-Qur'an, 9:60.

${ }^{6}$ Rafika Ariandini, "Pribumisasi Islam dalam Tafsir al-Azhar Pada QS. At-Taubah ayat 60 tentang Mustahiq Zakat," MAGHZA: Jurnal Ilmu Al-Qur'an dan Tafsir 4, no. 2 (24 Desember 2019): 232-48, https://doi.org/10.24090/maghza.v4i2.3167.

7 Irfandi Ez dan Nurul Maisyal, "Pendayagunaan Zakat Untuk Penanggulangan Pandemi Covid-19 Perpektif Filsafat Hukum Islam," Al - Muamalat: Jurnal Hukum Dan Ekonomi Syariah 5, no. 1 (26 September 2020): 1-26, https://doi.org/10.32505/muamalat.v5i1.1849.

8 Ayu Rahmatul Ainiyah dan Airlangga Bramayudha, "Kegiatan Pendistribusian Zakat Produktif Pemberdayaan UMKM di LAZIZMU Kabupaten Gresik," Journal of Islamic Management 1, no. 2 (25 Juli 2021): 14-31, https://doi.org/10.15642/jim.v1i2.553.

9 "Institutional Repository UIN Syarif Hidayatullah Jakarta: Perbandingan ijtihad yusuf alqaradawi dan wahbah zuhaili tentang zakat perusahaan," 1-93, diakses 13 Agustus 2021, https://repository.uinjkt.ac.id/dspace/handle/123456789/46460. 
Perbedaan dengan kajian ini terletak pada objek yang lebih fokus membahas tentang asnaf zakat.

Kedua, penelitian Tajudin Heru Cokro ${ }^{10}$ tentang "Analisis Terhadap Fatwa Yūsuf Al-Qarḍawi Tentang Makna 'Fi Sabilillah' Dalam QS. Al-Taubah Ayat 60 Mengenai Mustahik Zakat." Penelitian tersebut menguraikan bahwa sabilullah merupakan salah satu dari ashnaf zakat yang bermakna umum yaitu perang di jalan Allah dan juga bermakna khusus yakni segala hal baik yang bertujuan untuk menggapai ridho Allah. Perbedaan dengan kajian ini terletak pada subjek dan objek yang mengkomparasikan dua pemikiran tokoh tentang mustahik zakat.

Ketiga, penelitian tentang "Analisis Pemikiran Yūsuf Al-Qarḍawi dan Wahbah Al-Zuhayli Tentang Zakat Profesi dan Relevansinya Di Indonesia”, yang ditulis Ika Mardiana Ramadhani. ${ }^{11}$ Penelitian tersebut menguraikan pendapat Yūsuf Al Qarḍawi tentang adanya zakat profesi adalah, zakat profesi dapat dianalogikan dengan zakat uang. Sedangkan menurut Wahbah Al Zuhayli harta yang akan dikeluarkan zakatnya harus memenuhi persyaratan yang telah ditentukan syara'.

Keempat, penelitian tentang "Penggunaan Dana Zakat Untuk Istitsmār (Investasi) Studi Komparatif Distribusi Zakat Menurut Wahbah Al Zuhayli dan YūSuf Al Qarḍawi," yang ditulis Rosid Adnan.12 Dalam penelitian tersebut dijelaskan bahwa Wahbah berpendapat bahwa zakat tidak boleh diinvestasikan dalam bidang apapun, sedangkan menurut Qardhawi boleh saja. Perbedaannya dengan kajian ini terletak pada objeknya, yakni lebih fokus pada makna kata sabilillah.

Berdasarkan berbagai penelitian tersebut, kajian ini memiliki fokus yang baru dan berbeda, serta penting untuk diteliti. Pertanyaan penelitian ini fokus pada bagaimana analisis komparasi pemikiran Yūsuf Al Qarḍwi dan Wahbah Al

10 Tajudin Heru Cokro, "Analisis terhadap fatwa Yusuf Qardhawi tentang makna 'fi sabilillah' dalam QS. Al-Taubah ayat 60 mengenai mustahik zakat" (undergraduate, IAIN Jember, 2015), 1-101, http://digilib.iain-jember.ac.id/352/.

11 Ika Mardiana Ramadhani, “Analisis Pemikiran Yu>suf Al Qard\{awi> Dan Wahbah Alzuhayli>Tentang Zakat Profesi Dan Relevansinya Di Indonesia" (IAIN Ponorogo, t.t.), 1-85, http://etheses.iainponorogo.ac.id/5040/1/ika\%20mardiana\%20ramadhani.pdf.

12 Adnan Rosid, "Penggunaan dana zakat untuk istitsmār (investasi) (studi komparatif distribusi zakat menurut Wahbah al-Zuhaili dan Yusuf al-Qaradhawi)," 10 Mei 2019, 1-98, https://repository.uinjkt.ac.id/dspace/handle/123456789/46492. 
Zuhayli? dan bagaimana analisis komparasi metode istinbāth hukum Yūsuf Al Qardawi dan Wahbah Al Zuhayli tentang konsep asnaf penerima zakat dalam Islam?

Salah satu perbedaan yang paling signifikan ialah pada asnaf fi sabilillaah, menurut Yūsuf Al Qardawi mengartikan bahwa golongan tersebut tidak hanya khusus pada jihad dan yang berhubungan dengannya, akan tetapi ditafsirkan pada semua hal yang mencakup perbuatan-perbuatan baik. ${ }^{13}$ Sedangkan salah satu pemikiran Wahbah Al Zuhayli pada arti sabilillah adalah para mujahid yang berperang yang tidak mempunyai hak dalam honor sebagai tentara, karena jalan mereka adalah mutlak berperang. Masih ada beberapa golongan yang kiranya harus dibahas dan dikaji. Begitu urgensinya peran zakat dalam Islam untuk membatu sesama manusia dalam kebutuhannya, dalam perekonomian yang sangat tidak mampu dalam memenuhi sehari-hari. ${ }^{14}$

Metode yang digunakan adalah penelitian hukum normatif melalui studi kepustakaan (library research). ${ }^{15}$ Langkah yang ditempuh yaitu dengan mengumpulkan data-data berkaitan konsep asnaf zakat ${ }^{16}$ menurut kedua tokoh dalam literaturnya yaitu Fiqhuz Zakat karya Yūsuf Al Qarḍawi dan Fiqh Islam wa Adillatuhu karya Wahbah Al Zuhayli. Selanjutnya analisis isi dilakukan dengan bersumber pada beberapa buku, jurnal, website dan lain-lain. Sehingga akan menemukan kesimpulan dengan menampilkan pandangan terbaik dari data-data yang ada.

\section{ANALISIS KOMPARASI PEMIKIRAN YUSUF AL QARDAWI DAN WAHBAH AL ZUHAYLI TENTANG KONSEP ASNAF PENERIMA ZAKAT DALAM ISLAM}

Dalam Q.S. at-Taubah ayat 60, Allah telah menetapkan bahwa terdapat delapan golongan orang yang layak menerima zakat sebagaimana yang disebut di dalam ayat tersebut. ${ }^{17}$ Menurut Yūsuf Al Qardawi sejak datangnya agama Islam

13 Yusuf Qaradawi dkk., Hukum Zakat: Studi Komparatif Mengenai Status Dan Filsafat Zakat Berdasarkan Quran Dan Hadis (Bogor, Jakarta: Litera Antar Nusa, 2007), 618-19.

14 Harisah Hoironi, "Peran Zakat Dalam Pemulihan Ekonomi Saat Pandemi Covid-19," Syar'ie 4, no. 1 (11 Februari 2021): 54-66, https://doi.org/10.51476/syar'ie.v4i1.242.

${ }^{15}$ Ahmad Rofi'i Harahap, "Pendapat Abu Hanifah Tentang Kewajiban Membayar Zakat Pada Tanah Sewa," AHKAM: Jurnal Syariah dan Hukum 1, no. 2 (22 Juli 2021): 134-48.

16 "Asnaf Zakat Dan Pendistribusiannya: Tinjauan Fikih Dan Ekonomi Kontemporer |

Hambari | Kasaba: Jurnal Ekonomi Islam,” 9-15, diakses 12 Agustus 2021, http://150.107.142.43/index.php/Kasaba/article/view/3393.

17 Balwi, "Mobilisasi Zakat Dalam Pewujudan Usahawan Asnaf: Satu Tinjauan." 
maka perhatian pertama mengenai keuangan negara telah ditujukan kepada golongan yang sangat membutuhkan. Bagian terbesar harta zakat khusus diperuntukkan bagi mereka yang berhak menerima, di samping dari perbelanjaan negara, hal ini telah dijadikan tujuan dan jangkauan sosial yang luas sekali. ${ }^{18} \mathrm{Hal}$ tersebut kemudian berdampak pada beragamnya pemikiran tentang golongan penerima zakat sesuai dengan perkembangan zaman dan perubahan waktu.

Adanya perbedaan pemikiran kedua tokoh yakni Yūsuf Al Qardawī Dan Wahbah Al Zuhayli dapat berakibat pada beragamnya praktik pemberian harta zakat di masa kini. Karena keduanya memiliki corak pemikiran serta dasar dalam pengambilan pendapat yang berbeda. Tidak hanya itu, konsep dari keduanya memiliki kekuatan serta kelemahan masing-masing, hal itu didasari oleh kehidupan sosial kedua tokoh yang pasti berbeda. Berikut penjelasan mengenai delapan golongan perspektif Yūsuf Al Qardawī Dan Wahbah Al Zuhayli.

Pertama, Fakir. Golongan ini disebutkan dalam Qur'an yakni melalui kata لِلْفُرَاءٍ yang bermakna orang-orang fakir. Mayoritas ulama memang berbeda pendapat mengenai golongan yang pertama ini. Pendapat Yūsuf Al Qarḍawỉ bahwa fakir yaitu orang yang dalam kebutuhan tapi dapat menjaga diri tidak mintaminta. ${ }^{19}$ Sedangkan Wahbah Al Zuhayli juga menyebutkan bahwa fakir adalah orang yang tidak memiliki harta dan pekerjaan yang dapat mencukupi kebutuhannya dan pendapatnya ini disandarkan pada pendapat ulama Syafi'iyah dan Hanabilah. ${ }^{20}$ Dengan demikian pengertian fakir adalah golongan yang memerlukan bantuan. Namun bisa dikatakan bahwa orang fakir masih mempunyai potensi untuk memenuhi kebutuhan hidupnya. ${ }^{21}$ Zakat diserahkan kepada orang fakir guna menyambung kehidupannya secara normal. ${ }^{22}$ Pendapat Yūsuf Al Qardawi dan Wahbah Al Zuhayli sekilas memang nampak sama, sebab orang fakir

${ }^{18}$ Qaradawi dkk., Hukum Zakat, 509.

${ }^{19}$ Qaradawi dkk., 510.

20 Wahbah al-Zuhayli dan Abdul Hayyie Al-Kattani, Fiqih Islam wa adillatuhu (Kuala Lumpur: Darul Fikir, 2010), 281.

21 Sidqi Ahyani, "Kemiskinan Dalam Perspektif Al-Qur`an Dan Solusinya Dalam Pandangan Islam: Studi Pemikiran Sa'ad Ibrahim dan Yusuf Qardhawi Tentang Penanggulangan Kemiskinan," Jurnal Kariman 4, no. 1 (2016): 43-64, https://doi.org/10.52185/kariman.v4i1.61.

22 "Skala Prioritas Penentuan Mustahiq Zakat Di Lembaga Amil Zakat (LAZ) Ummat Sejahtera Ponorogo | Lisyabab," 103-18, diakses 12 Agustus 2021, https://lisyabab-staimas.ejournal.id/lisyabab/article/view/72. 
memanglah mereka yang sebenarnya terimpit kebutuhan akan tetapi tidak dapat memenuhi segala kebutuhannya itu karena ia sendiri dalam keadaan tidak memiliki harta sama sekali.

Kedua, Miskin. Menurut Yūsuf Al Qardawī bahwa miskin adalah orang yang sedang dalam kebutuhan tapi suka merengek-rengek dan suka minta-minta. ${ }^{23}$ Sedangkan menurut Wahbah Al Zuhayli berpendapat bahwa orang miskin adalah orang yang mampu untuk bekerja untuk menutupi kebutuhannya, namun belum mencukupi, seperti orang yang membutuhkan sepuluh dan dia hanya mempunyai delapan, sehingga tidak mencukupi kebutuhan sandang, pangan, dan papannya. ${ }^{24}$ Dalam hal ini orang miskin berpotensi rendah atau bahkan tidak memiliki potensi dalam diri, sehingga untuk memenuhi kebutuhan hidup dasarnya saja mereka kesulitan. ${ }^{25}$ Kedua pemikiran ini memang sesuai, sebab orang miskin memang memiliki kebutuhan dan juga memiliki suatu hal bisa dalam bentuk harta atau pekerjaan sehingga bisa memenuhi kebutuhannya walaupun tidak sepenuhnya tertutupi. Namun tetap saja jika dianalisis bahwa orang miskin tetap berada pada garis kekurangan sehingga sangat tepat diberi harta zakat.

Ketiga, Amil. Pelaksanaan zakat biasanya diserahkan kepada amil zakat, sehingga praktik zakat berjalan dengan baik sesuai tuntunan syari'at Islam. Zakat yang dikumpulkan dari muzakki, langsung dibagikan kepada mustahik. ${ }^{26}$ Menurut Y ūsuf Al Qardawi yang dimaksudkan dengan amil zakat yaitu mereka yang melaksanakan segala kegiatan urusan zakat, mulai dari para pengumpul, sampai kepada bendahara dan para penjaganya. Juga mulai dari pencatat sampai kepada penghitung yang mencatat keluar masuk zakat, dan membagi kepada para mustahiknya. ${ }^{27}$ Sedangkan menurut Wahbah Al Zuhayli bahwa panitia zakat adalah orang-orang yang bekerja memungut zakat. ${ }^{28}$ Amil zakat bisa disebut juga sebagai

${ }^{23}$ Qaradawi dkk., Hukum Zakat, 511.

24 al-Zuhayli dan Al-Kattani, Fiqih Islam wa adillatuhu, 282. Islam."

25 Ahyani, "Kemiskinan Dalam Perspektif Al-Qur`an Dan Solusinya Dalam Pandangan

26 Moh. Taufik Hidayat, Tri Handayani, dan Ubbadul Adzkiya', “Zakat Fitrah kepada Dukun Bayi dalam Perspektif Hukum Islam," iqtisad Reconstruction of Justice and Welfare for Indonesia, t.t., 99-118.

27 Qaradawi dkk., Hukum Zakat, 545.

28 al-Zuhayli dan Al-Kattani, Fiqih Islam wa adillatuhu, 283. 
"pihak yang diangkat oleh penguasa atau badan perkumpulan untuk mengelola zakat". ${ }^{29}$

Salah satu kekuatan pemikiran Yūsuf Al Qarḍawi adalah bahwa amil zakat bukan hanya mereka yang bertugas membagikan harta zakat saja, akan tetapi juga mereka yang mengumpulkan sampai kepada bendahara dan para penjaganya, lalu mencatat sampai kepada penghitung yang mencatat keluar masuk zakat, dan membagikan harta zakat kepada para mustahiknya. Jadi tugas dan tanggung jawab amil zakat memang sangatlah besar karena memikul amanah untuk ditasyarufkan kepada mereka yang berhak menerima. Sedangkan pemikiran Wahbah Al Zuhayli tentang amil zakat juga memiliki kekuatan dimana seorang amil disyaratkan mereka yang adil, memahami hukum zakat, dapat menulis, dan bisa menjaga harta. Pendapatnya ini cukup kuat karena memang seorang amil adalah orang pilihan dan bukan hanya orang biasa, dalam artian mereka diharuskan cakap dan juga paham aturan-aturan zakat.

Keempat, Mualaf. Menurut Yūsuf Al-Qarḍawī yang dimaksud dengan golongan mualaf antara lain adalah mereka yang diharapkan kecenderungan hatinya atau keyakinannya dapat bertambah terhadap Islam, atau terhalangnya niat jahat mereka atas kaum Muslimin, ${ }^{30}$ serta para mualaf yang dibujuk hatinya dengan harapan akan adanya manfaat mereka dalam membela dan menolong umat Islam dari musuh. ${ }^{31}$ Sedangkan menurut Wahbah Al Zuhayli yang termasuk dalam kelompok ini antara lain orang-orang yang lemah niatnya untuk memasuki Islam. ${ }^{32}$ Perbedaan pendapat kedua tokoh ini sangat tipis sekali. Karena dalam maknanya, mualaf sendiri diartikan secara bahasa sebagai orang yang baru masuk Islam.

Kelima, Riqab atau memerdekakan budak. Menurut Yūsuf Al Qarḍwì riqab adalah bentuk jamak dari raqabah. Istilah ini dalam al-Qur'an artinya budak belian

29 "Efektivitas Program Penyaluran Dana Zakat Profesi Dalam Bentuk Pemberian Beasiswa Bagi Siswa Muslim Kurang Mampu oleh Badan Amil Zakat Nasional (BAZNAS) di Kabupaten Tabanan Tahun 2015 | . | Jurnal Pendidikan Ekonomi Undiksha," 1-11, diakses 12 Agustus 2021, https://ejournal.undiksha.ac.id/index.php/jjpe/article/view/7676.

30 Qaradawi dkk., Hukum Zakat, 563.

31 "Analisis Efektivitas Penyaluran Zakat pada Rumah Zakat | Bahri | Al Maal: Journal of Islamic Economics and Banking," 13-24, diakses 12 Agustus 2021, http://jurnal.umt.ac.id/index.php/jieb/article/view/2642.

32 al-Zuhayli dan Al-Kattani, Fiqih Islam wa adillatuhu, 283. 
laki-laki (abid) dan budak belian perempuan (amah). ${ }^{33}$ Istilah ini diterangkan dalam kaitannya dengan pembebasan atau pelepasan, seolah-olah al-Qur'an memberikan isyarah dengan kata kiasan ini maksudnya bahwa perbudakan bagi manusia tidak ada bedanya seperti belenggu yang mengikatnya. Dengan harapan mereka bisa merdeka sebagaimana manusia pada umumnya. Sedangkan menurut Wahbah Al Zuhayli para budak yang dimaksudkan disini menurut jumhur ulama ialah para budak Muslim yang telah membuat perjanjian dengan tuannya (almukatabun $)^{34}$ untuk dimerdekakan dan tidak memiliki uang untuk membayar tebusan atas diri mereka, meskipun mereka telah bekerja keras dan membanting tulang mati-matian. ${ }^{35}$ Persoalannya adalah bagaimana cara menemukan kembali golongan penerima zakat yakni budak belian seperti pada keterangan dua tokoh ini. Sementara saat ini berbagai negara telah menghapuskan sistem perbudakan.

Kelima, Gharim. Menurut Yūsuf Al Qarḍawi Gharimun merupakan bentuk jamak dari gharim (dengan ghain panjang), artinya orang yang mempunyai utang. Sedangkan ghariim (dengan ra panjang) adalah orang yang berutang, kadangkala pula dipergunakan untuk orang yang mempunyai piutang. ${ }^{36}$ Sedangkan menurut Wahbah Al Zuhayli mereka adalah orang-orang yang mempunyai banyak utang. ${ }^{37}$ Harta zakat baru akan diberikan kepada orang yang memiliki utang untuk hidup dirinya sendiri maupun untuk kemaslahatan orang lain.

Keenam, Fi Sabilillah. Menurut Yūsuf Al-Qardawi yang didasarkan pada pendapat ulama terdahulu bahwa sabilillah mutlak diartikan sebagai bentuk jihad. Pemaknaan jihad atau perang dengan perbuatan disandarkan pada makna kutipan beliau bahwa berjuang di jalan Allah bisa saja dilakukan dengan perbuatan, sehingga nampaknya memang sangat familiar didengar bahwa jihad selalu identik dengan perbuatan atau 'amalan. Namun hal yang menarik dari Yūsuf Al Qardawī yaitu dengan mengambil pula pendapat beberapa ulama yang meluaskan makna sabilillah sehingga tidak hanya jihad dengan menggunakan senjata atau peperangan. Pemikiran Yūsuf Al Qarḍawī ini memang perlu dikembangkan atau

33 Qaradawi dkk., Hukum Zakat, 587.

34 Al-mukatab ialah budak yang dijanjikan oleh tuannya untuk dimerdekakan bila dia telah membayar sejumlah uang.

35 al-Zuhayli dan Al-Kattani, Fiqih Islam wa adillatuhu, 285.

${ }^{36}$ Qaradawi dkk., Hukum Zakat, 594.

37 al-Zuhayli dan Al-Kattani, Fiqih Islam wa adillatuhu, 285. 
dikorelasikan dengan keadaan sekarang. Menilik jaman sekarang sulit menemukan golongan satu ini. Jika masih ada peperangan seperti yang terdapat pada masa Rasulullah, konfliknya pun pasti berbeda.

Harta zakat boleh saja diberikan kepada mutlak para mujahid jika di suatu daerah memang mutlak terdapat seorang atau sekelompok orang yang berjihad. Akan tetapi merujuk pada pendapat Imam ar-Razi dalam tafsirnya, bahwa zahir lafaz dalam firman Allah "wa fi sabilillah" tidak wajib mengkhususkan artinya pada orang yang berperang saja. Kemudian ia berkata: "Maka terhadap arti ini, Imam Qaffal mengutip dalam tafsirnya dari sebagian fuqaha, bahwa mereka itu memperkenankan menyerahkan zakat, pada semua bentuk kebajikan, seperti mengurus mayat, mendirikan benteng, meramaikan masjid". ${ }^{38}$ Berdasarkan salah satu pendapat tersebut, maka sebenarnya boleh saja zakat diberikan atau dipergunakan untuk hal-hal yang sesuai dengan keadaan saat ini. Sebab zaman sekarang terutama di Negara Indonesia, tidak ada bahkan tidak diizinkan adanya peperangan yang mengatasnamakan agama Islam. Dan bahkan di luar negara Indonesia pun perang agama Islam juga jelas sudah dihapuskan. Maka untuk dapat mentasharrufkan harta zakat, dialihkan kepada hal-hal yang jauh lebih peting, seperti untuk membangun jembatan, masjid, sekolah, dan kegiatan maslahat lainnya.

Selain itu, menurut Wahbah Al Zuhayli sabilillah diartikan sebagai bentuk kepedulian terhadap hal-hal maslahah, seperti ibadah haji. Pendapatnya ini juga didasarkan riwayat Abu Dawud dari Ibn Abbas yang mengatakan bahwa "Ada seseorang yang memberikan untanya utuk suatu keperluan di jalan Allah dan istrinya hendak menunaikan ibadah haji. Maka Nabi SAW bersabda kepada perempuan itu: 'Naikilah unta itu karena sesungguhnya haji merupakan salah satu bentuk perjuangan di jalan Allah."39 Berdasarkan riwayat tersebut, maka pemikiran Wahbah Al Zuhayli akan tepat sekali jika dimaknai bahwa harta zakat bisa saja diberikan kepada segala bentuk kemaslahatan dan taqarrub kepada Allah SWT. Bentuk dari hal baik tersebut tentunya juga beragam, dan Wahbah Al Zuhayli lebih mengutamakan seperti ibadah haji.

38 Qaradawi dkk., Hukum Zakat, 619.

39 al-Zuhayli dan Al-Kattani, Fiqih Islam wa adillatuhu, 286. 
Kedelapan, Ibnu sabil. Asnaf zakat yang terakhir yaitu ibnu sabil. Menurut Yūsuf Al Qardawi As-sabil artinya al-tharíq/jalan. Ibnu sabil juga dimaknai sebagai mereka yang berjalan dari satu daerah ke daerah lain. Dikatakan untuk orang yang berjalan diatasnya (ibnu sabil) karena tetapnya di jalan itu. Jalan yang tetap itu tentu memiliki makna tersendiri, seperti perjalanan seseorang demi memperjuangkan agamanya. ${ }^{40}$ Sedangkan menurut Wahbah Al Zuhayli orang yang sedang melakukan perjalanan adalah orang-orang yang bepergian (musafir) untuk melaksanakan suatu hal yang baik (thā'ah) tidak termasuk maksiat. ${ }^{41}$ Kedua pendapat tokoh ini seakan memiliki kesinambungan. Bahwa ibnu sabil atau orang yang sedang dalam perjalanan memang selayaknya mendapatkan bagian dari zakat. Akan tetapi satu keistimewaan dari pendapat Wahbah Al Zuhayli yaitu mencantumkan bahwa ibnu sabil akan diberi harta zakat manakala perjalanan yang dilakukan merupakan suatu hal yang baik dan tidak termasuk kemaksiatan.

\section{ANALISIS KOMPARASI ISTINBATH HUKUM YUSUF AL QARDAWI DAN WAHBAH AL ZUHAYLI TENTANG ASNAF PENERIMA ZAKAT DALAM ISLAM}

Mengenai istinbāth hukum tentang asnaf zakat, terlebih dahulu harus dicari landasan hukumnya yang terdapat dalam Q.S. at-Taubah:60. Terkait dengan metode istinbāth yang dilakukan oleh Yūsuf Al Qardawī untuk menemukan pemikiran tentang asnaf penerima zakat pada kitab Fiqh al-Zakat, sebagaimana telah dijelaskan di atas, Yūsuf Al Qarḍawī berpijak pada ayat-ayat al-Qur'an dan juga hadith sebagai dasar utama. Namun beliau juga menegaskan adanya pendapat atau pemikiran ulama terdahulu yang lebih dulu meneliti dan mengeluarkan pemikirannya terkait asnaf zakat.

Metode istinbāth hukum Yūsuf Al Qarḍawi mulai dari golongan asnaf zakat yang pertama yakni fakir dan miskin, sampai pada amil, mualaf, riqab, gharim, fi sabilillah dan ibnu sabil kebanyakan menggunakan ijma' para ulama yang pemikirannya telah mengisi sudut pengetahuan sejak dahulu. Seperti pendapat mazhab empat yakni Hanafi, Syafi'i, Maliki dan Hanbali. Selain itu Yūsuf Al Qardawī juga menukil pendapat beberapa ulama kontemporer yang hidup sejaman dengan beliau. Sebab Yūsuf Al Qarḍawī dirasa sebagai seorang ulama yang banyak

${ }^{40}$ Qaradawi dkk., Hukum Zakat, 645.

41 al-Zuhayli dan Al-Kattani, Fiqih Islam wa adillatuhu, 287. 
memberikan sumbangsih terhadap perkembangan hukum zakat di negara-negara yang mayoritas penduduknya adalah Islam.

Yūsuf Al Qardawī juga memiliki pemikiran tentang meluaskan makna $f i$ sabilillah yakni tidak hanya mutlak diartikan berperang saja. Tetapi juga bisa diartikan sebagai segala perbuatan baik untuk kemaslahatan. Dalam hal ini mungkin akan bertolak belakang dengan makna fi sabilillah secara bahasa yaitu jihad atau di jalan Allah. Namun hal itu juga merupakan salah satu upaya untuk mengalokasikan dana zakat agar tetap mengisi semua sudut kehidupan dan agama. Dalam konteks era ini jihad bisa menggunakan lisan dan pena, senada dengan pendapat Yūsuf Al-Qarḍawi kendati tidak sama dengan jihad dalam arti tekstual (perang). Akan tetapi, dengan menggunakan qiyas, hukum jihad (perang) dan Jihad (non-perang) bisa disamakan dengan illat yang sama yakni Nusrotul Islam (memperjuangkan/membela agama Allah SWT). ${ }^{42}$

Dan dalam hal pemikiran beliau tentang golongan penerima zakat, Yūsuf Qardawi hanya memaparkan pendapat-pendapat terdahulu. Dasar hukum yang digunakan beliau hanya realitas sosial yang terjadi ${ }^{43}$ dan benar-benar sesuatu yang urgent di kehidupan nyata. Maka konsep beliau dirasa relevan jika diterapkan di negara Indonesia.

Sedangkan metode istinbāth hukum Wahbah Al Zuhayli dalam kitabnya fikih islam wa adillatuhu juga menegaskan beberapa metode yang digunakannya. Seperti menggunakan dasar ayat al-Qur'an dan hadis sebab memang kedua dasar itulah sumber utama sebuah hukum. Lalu Wahbah Al Zuhayli juga menggunakan ijma' ulama sebagai dasar kedua beliau menentukan pemikirannya tentang konsep asnaf penerima zakat dalam Islam. Namun disini ada sedikit perbedaan yang sekaligus menjadi ciri utama perbedannya dengan pendapat Yūsuf Al Qardawi yaitu pada golongan amil dan ibnu sabil. Pada dua golongan ini, Wahbah Al Zuhayli tidak menggunakan dasar yang pasti seperti sebuah dalil ataupun ijma'. Namun

42 M. Maulana Asegaf, "Analisis Fatwa MUI Tahun 1982 tentang Mentasharufkan Dana Zakat untuk Kegiatan Produktif dan Kemaslahanatan Umum (Perspektif Yusuf Qardhawi)," Management of Zakat and Waqf Journal (MAZAWA) 2, no. 1 (30 September 2020): 1-20, https://doi.org/10.15642/mzw.2020.2.1.1-20.

43 "Analisis pendapat Yusuf Qardhawi tentang anak buangan sebagai mustahik zakat dari kelompok ibnu sabil dalam kitab Fiqh al-Zakat - Walisongo Repository," 1-120, diakses 13 Agustus 2021, http://eprints.walisongo.ac.id/id/eprint/7678/. 
dalam kitabnya beliau hanya menuliskan saja bagaimana pendapatnya tentang arti amil dan ibnu sabil. Hal ini bisa saja karena memang beliau langsung memaknai sendiri makna dua golongan tersebut dari al-Qur'an. Sehingga bisa disebut beliau juga melakukan ijtihad dalam menemukan pemikirannya sendiri.

Kedua tokoh ini memiliki keistimewaan tersendiri dalam menggali sebuah pemikiran. Meskipun begitu istinbāth hukum yang dilakukan oleh kedua tokoh tentu memiliki kekuatan dan kelemahan. Seperti Yūsuf Al Qardawi lebih menekankan pada dalil-dalil naqli sebagai jembatan pemikirannya, selain itu beliau juga memperhatikan ijma' para ulama dimana ijma' juga merupakan salah satu metode berijtihad. Namun berbeda dengan Wahbah Al Zuhayli dalam berijtihad beliau banyak menggunakan metode ijma', akan tetapi juga merumuskan pendapatnya sendiri terkait dengan dua asnaf zakat dari delapan asnaf. Hal tersebut tentu telah melalui proses panjang dimana Wahbah Al Zuhayli juga berusaha memahami makna dalam al-Qur'an dengan usahanya sendiri (berijtihad sendiri).

Meskipun begitu, namun mayoritas pemikiran Wahbah Al Zuhayli pun didasarkan pada dalil dan ijma' para ulama. Karena sama dengan Yūufuf Al Qarḍawi bahwa Wahbah Al Zuhayli adalah juga ulama kontemporer yang pasti ketika beliau merumuskan pemikirannya tentang konsep asnaf penerima zakat dalam Islam tentu sebelumnya juga sudah ada beberapa ulama yang mengkajinya.

\section{PENUTUP}

Berdasarkan hasil penelitian penulis mengenai perspektif Yūsuf Al Qardawī dan Wahbah Al Zuhayli tentang konsep asnaf penerima zakat dapat disimpulkan bahwa pemikiran kedua tokoh tentang delapan golongan penerima zakat secara keseluruhan memang sama, meskipun secara praktis mungkin ada sedikit perbedaan yang paling signifikan pada golongan fi sabilillah. Yūusuf Al Qarḍawi lebih mengedepankan pendapat beberapa ulama yang meluaskan makna fi sabilillah itu. Yūsuf Al Qardawī juga lebih memilih jalan tengah yakni memperbolehkan harta zakat digunakan untuk kegiatan masyarakat seperti membangun masjid dan kepentingan umum masa kini. Sedangkan makna delapan asnaf menurut Wahbah Al Zuhayli juga tidak jauh berbeda dengan pendapat Yūsuf Al Qarḍwīi. Terdapat perbedaan dalam golongan fi sabilillah, bahwa menurutnya golongan fi sabilillah 
boleh saja diartikan sebagai sebuah perjalanan untuk melaksanakan kemaslahatan, seperti menjalankan ibadah haji. Selain itu fi sabilillah juga diartikan sebagai para tentara yang tidak diberi gaji oleh negara dan hanya mutlak untuk berperang, maka golongan ini boleh saja diberi harta zakat.

Metode istinbāth hukum zakat profesi prespektif al Qardạwi yang digunakan ialah dalil dalam al-Qur'an dan hadith dan juga ijma' ulama terdahulu. Dan dalam berijtihad, al Qardạwi menggunakan metode ijtihad akal dalam mengungkapkan pemikirannya. Sedangkan metode istinbäth menurut Wahbah al Zuhayli adalah hampir sama dengan al Qardạwì, dengan menggunakan dalil-dalil dan juga ijma' terhadap ulama terdahulu, lalu dengan itu mengeluarkan pemikirannya sendiri.

\section{DAFTAR PUSTAKA}

Ahyani, Sidqi. "Kemiskinan Dalam Perspektif Al-Qur`an Dan Solusinya Dalam Pandangan Islam: Studi Pemikiran Sa'ad Ibrahim dan Yusuf Qardhawi Tentang Penanggulangan Kemiskinan." Jurnal Kariman 4, no. 1 (2016): 4364. https://doi.org/10.52185/kariman.v4i1.61.

Al-Qur'an dan Terjemah Tajwid Warna. Kartasura: Madina Qur'an, 2019.

"Analisis Efektivitas Penyaluran Zakat pada Rumah Zakat | Bahri | Al Maal: Journal of Islamic Economics and Banking." Diakses 12 Agustus 2021. http://jurnal.umt.ac.id/index.php/jieb/article/view/2642.

"Analisis pendapat Yusuf Qardhawi tentang anak buangan sebagai mustahik zakat dari kelompok ibnu sabil dalam kitab Fiqh al-Zakat - Walisongo Repository." Diakses $13 \quad$ Agustus 2021. http://eprints.walisongo.ac.id/id/eprint/7678/.

Ariandini, Rafika. "Pribumisasi Islam dalam Tafsir al-Azhar Pada QS. At-Taubah ayat 60 tentang Mustahiq Zakat." MAGHZA: Jurnal Ilmu Al-Qur'an dan Tafsir 4, no. 2 (24 Desember 2019): $232-48$. https://doi.org/10.24090/maghza.v4i2.3167.

Asegaf, M. Maulana. “Analisis Fatwa MUI Tahun 1982 tentang Mentasharufkan Dana Zakat untuk Kegiatan Produktif dan Kemaslahanatan Umum (Perspektif Yusuf Qardhawi)." Management of Zakat and Waqf Journal (MAZAWA) 2, no. 1 (30 September 2020): 1-20. https://doi.org/10.15642/mzw.2020.2.1.1-20.

"Asnaf Zakat Dan Pendistribusiannya: Tinjauan Fikih Dan Ekonomi Kontemporer | Hambari | Kasaba: Jurnal Ekonomi Islam." Diakses 12 Agustus 2021. http://150.107.142.43/index.php/Kasaba/article/view/3393.

Balwi, Mohd Abd Wahab Fatoni Mohd. "Mobilisasi Zakat Dalam Pewujudan Usahawan Asnaf: Satu Tinjauan." Jurnal Syariah 16, no. 3 (1 September 2008): 567-84.

Cokro, Tajudin Heru. "Analisis terhadap fatwa Yusuf Qardhawi tentang makna 'fi sabilillah' dalam QS. Al-Taubah ayat 60 mengenai mustahik zakat." Undergraduate, IAIN Jember, 2015. http://digilib.iain-jember.ac.id/352/. 
"Efektivitas Program Penyaluran Dana Zakat Profesi Dalam Bentuk Pemberian Beasiswa Bagi Siswa Muslim Kurang Mampu oleh Badan Amil Zakat Nasional (BAZNAS) di Kabupaten Tabanan Tahun 2015 | . | Jurnal Pendidikan Ekonomi Undiksha." Diakses 12 Agustus 2021. https://ejournal.undiksha.ac.id/index.php/jjpe/article/view/7676.

Ez, Irfandi, dan Nurul Maisyal. "Pendayagunaan Zakat Untuk Penanggulangan Pandemi Covid-19 Perpektif Filsafat Hukum Islam." Al - Muamalat: Jurnal Hukum Dan Ekonomi Syariah 5, no. 1 (26 September 2020): 1-26. https://doi.org/10.32505/muamalat.v5i1.1849.

Harahap, Ahmad Rofi'i. "Pendapat Abu Hanifah Tentang Kewajiban Membayar Zakat Pada Tanah Sewa." AHKAM: Jurnal Syariah dan Hukum 1, no. 2 (22 Juli 2021): 134-48.

Hidayat, Moh. Taufik, Tri Handayani, dan Ubbadul Adzkiya'. "Zakat Fitrah kepada Dukun Bayi dalam Perspektif Hukum Islam." iqtisad Reconstruction of Justice and Welfare for Indonesia, t.t.

Hoironi, Harisah. "Peran Zakat Dalam Pemulihan Ekonomi Saat Pandemi Covid19." Syar'ie 4, no. 1 (11 Februari 2021): 54-66. https://doi.org/10.51476/syar'ie.v4i1.242.

"Institutional Repository UIN Syarif Hidayatullah Jakarta: Perbandingan ijtihad yusuf al-qaradawi dan wahbah zuhaili tentang zakat perusahaan." Diakses 13

Agustus

2021.

https://repository.uinjkt.ac.id/dspace/handle/123456789/46460.

Jazuli, Ahmad Imam. "Makna Fisabilillah Sebagai Mustahiq Zakat (Studi Komparasi Antara Ahlus Sunnah Wal Jama'ah Dan Wahabi)." Journal of Islamic Business Law 5, no. 1 (31 Maret 2021). http://urj.uinmalang.ac.id/index.php/jibl/article/view/624.

"Pandangan Ulama Tentang Zakat Perusahaan | Syakhsia : Jurnal Hukum Perdata Islam." Diakses $\quad 12 \quad$ Agustus 2021. http://103.20.188.221/index.php/syakhsia/article/view/4879.

Qaradawi, Yusuf, Salmah Harun, Didin Hafidhuddin, dan Hasanuddin. Hukum Zakat: Studi Komparatif Mengenai Status Dan Filsafat Zakat Berdasarkan Quran Dan Hadis. Bogor, Jakarta: Litera Antar Nusa, 2007.

Rahmatul Ainiyah, Ayu, dan Airlangga Bramayudha. "Kegiatan Pendistribusian Zakat Produktif Pemberdayaan UMKM di LAZIZMU Kabupaten Gresik." Journal of Islamic Management 1, no. 2 (25 Juli 2021): 91-108. https://doi.org/10.15642/jim.v1i2.553.

Ramadhani, Ika Mardiana. "Analisis Pemikiran Yu>suf Al Qard\{awi> Dan Wahbah Alzuhayli>Tentang Zakat Profesi Dan Relevansinya Di Indonesia." IAIN Ponorogo,

t.t. http://etheses.iainponorogo.ac.id/5040/1/ika\%20mardiana\%20ramadhan i.pdf.

Rosid, Adnan. "Penggunaan dana zakat untuk istitsmār (investasi) (studi komparatif distribusi zakat menurut Wahbah al-Zuhaili dan Yusuf alQaradhawi)," $10 \quad$ Mei 2019. https://repository.uinjkt.ac.id/dspace/handle/123456789/46492. 


\section{Jurnal Antologi Hukum}

Vol. 1, No. 1, Juli 2021

"Skala Prioritas Penentuan Mustahiq Zakat Di Lembaga Amil Zakat (LAZ) Ummat Sejahtera Ponorogo | Lisyabab." Diakses 12 Agustus 2021. https://lisyababstaimas.e-journal.id/lisyabab/article/view/72.

Ubabuddin, dan Umi Nasikhah. "Peran Zakat, Infaq Dan Shadaqah Dalam Kehidupan." Al-Muttaqin : Jurnal Dakwah Dan Sosial Keagamaan 6, no. 1 (24 Februari 2021): 60-76.

Zuhayli, Wahbah al-, dan Abdul Hayyie Al-Kattani. Fiqih Islam wa adillatuhu. Kuala Lumpur: Darul Fikir, 2010.

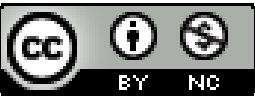

(C) 2021 by the authors. Submitted for possible open access publication under the terms and conditions of the Creative Commons Attribution-NonCommercial 4.0 International License (CC BY NC) license (https://creativecommons.org/licenses/bync/4.0/). 